\title{
GAMBARAN PENGETAHUAN IBU NEONATUS DINI 0-7 HARI TENTANG OMFALITIS DI WILAYAH KERJA PUSKESMAS KEBUNSARI KECAMATAN WONOMULYO KABUPATEN POLEWALI MANDAR TAHUN 2015
}

\begin{abstract}
NIAR
Latar Belakang : Bakteri memasuki tali pusat dan terjadi suatu infeksi yang disebut omfalitis. Tanda-tanda pertama adalah basahnya tali pusat, berbau, mengeluarkan sedikit cairan. Area disekitar tali pusat menjadi bengkak. Cairan yang dikeluarkan meningkat, baunya meningkat, dan lebih buruk lagi bayi mengalami demam karena infeksi meningkatkan toksik. Tanpa pengobatan, mungkin terjadi kematian dalam beberapa hari.

Tujuan Penelitian : ini untuk mengetahui gambaran pengetahuan ibu neonatus dini 0-7 hari tentang omfalitis di wilayah kerja puskesmas kebunsari kecamatan wonomulyo kabupaten polewali mandar tahun.

Metode Penelitian : yang digunakan adalah deskriptif kuantitatif, populasi yaitu semua ibu neonatus dini 0-7 hari sebanyak 36 orang. Teknik pengambilan sampel menggunakan accidental sampling dan jumlah sampel sebanyak 36 responden, dan Tekhnik analisis yang digunakan yaitu analisis Univariat.

Hasil Penelitian : didapat tingkat Pengetahuan Ibu Neonatus Dini 0-7 Hari Tentang Penyebab Omfalitis adalah cukup sebesar 66.7\%, Gejala Omfalitis adalah baik sebesar $52.8 \%$, dan Pencegahan Omfalitis adalah cukup sebesar 58.3\%.

Simpulan : Berdasarkan hasil penelitian secara keseluruhan Gambaran Pengetahuan Ibu Neonatus Dini 0-7 Hari Tentang Omfalitis adalah sebesar $66.7 \%$ termasuk dalam kategori cukup.
\end{abstract}

Kata kunci $\quad$ : Pengetahuan Ibu neonatus dini, Omfalitis.

\section{PENDAHULUAN}

Omfalitis adalah infeksi pada tali pusat bayi baru lahir yang ditandai dengan kulit kemerahan disertai pus yang disebabkan akibat kurangnya aseptik antiseptik saat pengguntingan dan perawatan tali pusat oleh bidan penolong persalinan. Hasil apus pus omfalitis adalah bakteri batang Gram negatif, sesuai dengan pola kuman yang sering menginfeksi bayi baru lahir ditandai dengan basahnya tali pusat, basah dan lengket, disertai bau yang tidak sedap. Area disekitar tali pusat menjadi bengkak. Penyebab infeksi ini adalah stafilokokus, stretokokus, atau bakteri gram negatif (Sinclair,2010:338).

Tali pusat biasanya puput lima hari sampai satu minggu setelah lahir dan luka sembuh dalam 15 hari. Sebelum luka sembuh merupakan jalan masuk untuk kuman dan infeksi yang dapat menyebabkan omfalitis. Pengenalan secara dini infeksi tali pusat sangat penting untuk mencegah omfalitis.

Tali pusat merupakan bagian yang penting untuk diperhatikan pada bayi yang baru lahir. Bayi yang baru lahir kurang lebih dua menit akan segera di potong tali pusatnya kira-kira dua sampai tiga sentimeter yang hanya tinggal pada pangkal pusat (umbilicus), dan sisa potongan inilah yang sering terinfeksi Staphylococcus aereus. Pada ujung tali pusat akan mengeluarkan nanah dan pada sekitar pangkal tali pusat akan memerah dan disertai edema (Musbikin, 2005).

Berdasarkan Human Development Report 2010, AKB di Indonesia mencapai 31 per 1.000 kelahiran, "Angka itu 5,2 kali lebih tinggi dibandingkan Malaysia, juga 1,2 kali lebih tinggi dibandingkan Filipina, dan 2,4 kali lebih tinggi jika dibandingkan dengan Thailand. Karena itu, masalah ini 
harus menjadi perhatian serius," ucap Yeni Fatmawati, Corporate Affairs Director, PT Sari Husada di Jakarta, Selasa (21/12/10). Hasil sementara SDKI tahun 2012 menunjukkan bahwa $\mathrm{AKB}$ naik menjadi 32 kematian per 1.000 kelahiran hidup yang mana di angka ini, 19 per 1.000 terjadi pada masa neonatal yaitu sejak lahir sampai usia 28 hari," terang dr Kirana Pritasari, Direktur Bina Kesehatan Anak Kementerian Kesehatan RI dalam acara Seminar 'Peningkatan Kualitas Asuhan Neonatus dalam Pelayanan Kesehatan' di Crowne Plaza Hotel, Jakarta, Rabu (27/2/2013). Berdasarkan hasil SDKI tersebut ditemukan bahwa sekitar lebih dari 80.000 bayi baru lahir meninggal dunia saat berusia kurang dari sebulan. Hampir 43 persen kematian bayi di bawah usia satu tahun terjadi pada 28 hari pertama kehidupan. Menurut laporan Save The Children mengenai kematian bayi pada tahun 2013 yang telah diluncurkan pada hari Selasa (25/2) mengungkapkan, kematian saat kelahiran di Indonesia menurun dari 390 per 100.000 anak pada tahun 1994 menjadi 228/100.000 kelahiran.

Lebih dari tiga perempat dari kematian bayi disebabkan oleh 3 penyebab utama, yaitu kesulitan bernafas saat lahir atau asfiksia, infeksi dan komplikasi lahir prematur dan berat badan lahir rendah. Para ahli sepakat bahwa sebagian besar kematian ini dapat dihindari. Bukti penelitian dari seluruh dunia telah menunjukkan bahwa kematian bayi baru lahir dapat dihindari dengan intervensi sederhana dan terjangkau yang semuanya dapat diterapkan di Indonesia.

Bayi baru lahir sangat rentan terkena masalah yang bisa mengancam kehidupannya. Misalnya masalah kebersihan. Kebersihan yang tidak dijaga bisa membuat bayi menjadi sakit bahkan meninggal.

Berdasarkan data AKB di Provinsi Sulawesi Barat tahun 2012 sebesar 14,5/1000 kelahiran hidup, meningkat bila dibandingkan dengan tahun 2011 sebesar
11,6/1000 kelahiran hidup. Masita mengungkapkan (pembicara dari Yasmib pada acara diskusi publik Rancangan Anggaran Pendapatan Belanja Daerah (RAPBD) Kabupaten Polman 2014, yang digelar di Warkop Dg Sija, Polewali, Senin 23 Desember 2013), untuk AKB Polman pada tahun 2011 yaitu 75 orang, tahun 2012 meningkat menjadi 109 orang, dan tahun 2013 turun menjadi 80 bayi. Pada tahun 2014 AKB meningkat, jumlah bayi yang meninggal sebanyak 94 bayi (DinKes Polman).

Kemampuan hidup sehat dimulai sejak bayi karena pada masa ini terjadi pertumbuhan dan perkembangan yang menentukan kualitas otak pada masa dewasa. Supaya terciptanya bayi yang sehat maka dalam perawatan tali pusat pada bayi baru lahir dilakukan dengan benar - benar sesuai dengan prosedur kesehatan.

Menurut Boycell (2011), tujuan perawatan tali pusat adalah untuk mencegah terjadinya penyakit tetanus pada bayi baru lahir, penyakit ini disebabkan karena masuknya spora kuman tetanus kedalam tubuh bayi melalui tali pusat, baik dari alat steril, pemakaian obat-obatan, bubuk atau daun-daunan yang ditaburkan ke tali pusat sehingga dapat mengakibatkan infeksi.

Berdasarkan jurnal penelitian, Hasil penelitian diperoleh mayoritas pengetahuan ibu tentang perawatan tali pusat untuk mencegah terjadinya infeksi sebelum penyuluhan adalah cukup sebanyak 31 orang $(83,8 \%)$. Mayoritas pengetahuan ibu tentang perawatan tali pusat untuk mencegah terjadinya infeksi setelah penyuluhan adalah baik sebanyak 31 orang $(83,8 \%)$. Ada perbedaan yang signifikan antara pengetahuan sebelum dan sesudah penyuluhan (Tri Hartini:2009).

Infeksi sebagai salah satu penyebab kematian, sebenarnya dapat dengan mudah dihindari dengan perawatan tali pusat yang baik, dan pengetahuan yang memadai tentang cara merawat tali pusat. Berdasarkan data yang diperoleh dari 
Dinas kesehatan Polewali Mandar, pada tahun 2014 terdapat 94 bayi yang meninggal dengan berbagai penyebab, diantaranya adalah kasus kematian karena sepsis yang berjumlah 6. Infeksi pada bayi dapat menyebabkan gizi kurang karena saat bayi sakit maka jumlah asupan nutrisi yang diberikan kepada bayi bisa saja berkurang karena bayi akan rewel/tidak tenang saat tubuhnya dalam keadaan sakit, dan berdasarkan data yang diperoleh dari Dinas Kesehatan Polewali Mandar jumlah anak yang mengalami gizi kurang sebanyak 1228 dan hanya 773 yang sembuh, dan wilayah Puskesmas Kebunsari dari 92 yang berstatus gizi kurang hanya 59 yang sembuh.

Salah satu upaya yang dapat dilakukan untuk menurunkan angka kesakitan (Morbilitas) dan angka kematian (Mortalitas) adalah dengan memberikan pelayanan kesehatan yang efektif pada masyarakat tentang perawatan tali pusat bayi, dalam melaksanakan upaya tersebut diperlukan sumberdaya manusia yang mempunyai kemampuan untuk memberikan pelayanan yang berkualitas yaitu dengan memberikan penyuluhan tentang kesehatan kepada masyarakat sehingga pengetahuan yang dimiliki oleh masyarakat diharapkan dapat mempengaruhi perilaku masyarakat terhadap kesehatan.

Berdasarkan studi pendahuluan yang dilakukan di Wilayah Kerja Puskesmas Kebunsari yang ada di wilayah kecamatan Wonomulyo, hanya 4 dari 10 bayi yang tali pusatnya dirawat dengan benar. Selebihnya ada yang terjadi infeksi pada tali pusatnya dimana tali pusatnya berbau dan mengeluarkan pus, hal ini dapat terjadi karena kurangnya kebersihan dalam METODE PENELITIAN

\section{Jenis dan Metode Penelitian}

Desain dalam penelitian ini adalah penelitian deskriptif. Penelitian ini dilakukan untuk mendapatkan gambaran pengetahuan tentang Omfalitis di Wilayah Kerja Puskemas Kebunsari Kecamatan Wonomulyo perawatan tali pusat dan ada pula orang tua bayi yang membungkus tali pusat bayinya menggunakan daun dan menaburi tali pusat dengan kopi. Saat dilakukan pengkajian lebih jauh, ternyata ada $5 \mathrm{ibu}$ yang sebelumnya sudah diberitahu oleh Bidan untuk tidak melakukan hal tersebut namun tetap membungkus tali pusat bayinya dengan daun karena Ia ingin mematuhi perintah mertuanya. Ibu tersebut tidak membantah karena menurut adat istiadat dan budaya setempat bahwa hal tersebut baik bagi bayinya.

Perawatan tali pusat sebenarnya sederhana, yang penting pastikan tali pusat dan area sekelilingnya selalu bersih dan kering. Perawatan menggunakan alkohol dan penutupan tali pusat sudah tidak dianjurkan lagi, perawatan cukup menggunakan air matang dan biarkan tali pusat tetap terbuka. Usahakan tali pusat tetap kering, untuk mengelap bisa menggunakan tissue atau kain kasa steril.

Untuk pencegahan terjadinya infeksi tali pusat sebaiknya tali pusat tetap dijaga kebersihannya, pada saat memandikan di minggu pertama sebaiknya tidak merendam bayi langsung ke dalam air mandinya karena akan menyebabkan basahnya tali pusat dan memperlambat proses pengeringan tali pusat. Namun dalam kehidupan masyarakat desa masih ada yang menggunakan metode perawatan tali pusat dengan daun jarak.

Berdasarkan uraian diatas, peneliti tertarik untuk melakukan penelitian tentang "Gambaran Pengetahuan Ibu Neonatus Dini 0-7 hari tentang Omfalitis di Wilayah Kerja Puskemas Kebunsari Kecamatan Wonomulyo Kabupaten Polewali Mandar Tahun 2015”.

\section{Lokasi dan Waktu Penelitian}

Penelitian ini bertempat di Puskesmas Kebunsari Kabupaten Polewali Mandar. Penelitian ini dilakukan pada bulan Oktober 2015

\section{Populasi dan Sampel}


Dalam penelitian ini yang menjadi populasi adalah semua ibu neonatus dini di Wilayah Puskemas Kebunsari sebanyak 36 orang dari bulan Oktober 2015. Sampel HASIL DAN PEMBAHASAN dalam penelitian ini adalah 36 orang termasuk ibu yang mendukung dan bisa membaca dan menulis.

\section{Hasil Penelitian}

Tabel 4.1

Distribusi Frekuensi Responden Menurut Umur di Wilayah Kerja Puskesmas Kebunsari Tahun 2015

\begin{tabular}{|c|c|c|c|}
\hline No & Umur Responden & Frekuensi & Persentase (\%) \\
\hline 1 & $<26$ & 8 & 22.2 \\
2 & $26-35$ & 26 & 72.2 \\
3 & $>35$ & 2 & 5.6 \\
\hline \multicolumn{2}{r|}{ Total } & $\mathbf{3 6}$ & $\mathbf{1 0 0}$ \\
\hline
\end{tabular}

Sumber : Data Primer

Berdasarkan tabel $\quad 4.1$ menunjukkan bahwa distribusi dari 36 responden menurut kelompok umur, yang berusia $<26$ tahun sebanyak 8 responden
(22.2\%), yang berusia 26-35 tahun sebanyak 26 responden (72.2\%), dan yang berusia $>35$ tahun sebanyak 2 responden atau $(5.6 \%)$.

Tabel 4.2

Distribusi Frekuensi Responden Berdasarkan Pendidikan di Wilayah Kerja Puskesmas Kebunsari Tahun 2015

\begin{tabular}{|c|c|c|c|}
\hline No & Pendidikan & Frekuensi & Persentase (\%) \\
\hline 1 & SD & 7 & 19.4 \\
2 & SMP & 11 & 30.6 \\
3 & SMA & 14 & 38.9 \\
4 & PT & 4 & 11.1 \\
\hline \multicolumn{2}{r|}{ Total } & $\mathbf{3 6}$ & $\mathbf{1 0 0}$ \\
\hline
\end{tabular}

Sumber : Data Primer

Berdasarkan tabel 4.2 menunjukkan bahwa distribusi dari 36 responden menurut tingkat pendidikan, yang berpendidikan SD sebanyak 7 responden (19.4\%), yang berpendidikan
SMP sebanyak 11 responden (30.6\%), yang berpendidikan SMA sebanyak 14 responden (38.9\%), dan yang berpendidikan PT (Perguruan Tinggi) sebanyak 4 responden $(11.1 \%)$.

Tabel 4.3

Distribusi Frekuensi Responden Berdasarkan Jenis Pekerjaan di Wilayah Kerja Puskesmas Kebunsari Tahun 2015

\begin{tabular}{|c|c|c|c|}
\hline No & Pekerjaan & Frekuensi & Persentase (\%) \\
\hline 1 & URT & 28 & 77.8 \\
2 & Wiraswasta & 5 & 13.9 \\
3 & PNS/Honorer & 3 & 8.3 \\
\hline \multicolumn{2}{r|}{ Total } & $\mathbf{3 6}$ & $\mathbf{1 0 0}$ \\
\hline
\end{tabular}


Berdasarkan tabel 4.3 bekerja sebagai Wiraswasta sebanyak 5 menunjukkan bahwa distribusi dari 36 responden $(13.9 \%)$ yang bekerja sebagai responden berdasarkan pekerjaan, PNS/Honorer sebanyak 3 responden responden dengan jenis pekerjaan URT sebanyak 28 responden $(77.8 \%)$, yang $(8.3 \%)$.

Tabel 4.4

Distribusi Frekuensi Responden Berdasarkan Paritas di Wilayah Kerja Puskesmas Kebunsari Tahun 2015

\begin{tabular}{|c|c|c|c|}
\hline No & Paritas & Frekuensi & Persentase (\%) \\
\hline 1 & 1 & 17 & 47.2 \\
2 & $2-4$ & 16 & 44.4 \\
3 & $>4$ & 3 & 8.3 \\
\hline \multicolumn{2}{|c|}{ Total } & $\mathbf{3 6}$ & $\mathbf{1 0 0}$ \\
\hline
\end{tabular}

Sumber : Data Primer

Berdasarkan Tabel $\quad 4.4$ menunjukkan bahwa distribusi dari 36 responden berdasarkan paritas, responden dengan jumlah paritas 1 sebanyak 17 Variabel Yang Diteliti

responden $(47.2 \%)$, jumlah paritas 2-4 sebanyak 16 responden $(44.4 \%)$ dan jumlah paritas $>4$ sebanyak 3 responden $(8.3 \%)$.

Tabel 4.4

Distribusi Frekuensi Tingkat Pengetahuan Responden Tentang Penyebab Omfalitis di Wilayah Kerja Puskesmas Kebunsari Tahun 2015

\begin{tabular}{|c|c|c|c|}
\hline No & Kategori & Frekuensi & Persentase (\%) \\
\hline 1 & Baik & 12 & 33.3 \\
2 & Cukup & 24 & 66.7 \\
3 & Kurang & 0 & 0.0 \\
\hline \multicolumn{2}{|c|}{ Total } & $\mathbf{3 6}$ & $\mathbf{1 0 0}$ \\
\hline
\end{tabular}

Sumber : Data Primer

Berdasarkan Tabel $\quad 4.4$ menunjukkan bahwa pengetahuan dari 36 responden tentang penyebab Omfalitis, sebanyak 12 responden $(33.3 \%)$ dalam

kategori baik, 24 responden $(66.7 \%)$ dalam kategori cukup, dan 0 responden $(0.0 \%)$ dalam kategori kurang.

Tabel 4.5

Distribusi Frekuensi Tingkat Pengetahuan Responden Tentang Gejala Omfalitis di Wilayah Kerja Puskesmas Kebunsari Tahun 2015

\begin{tabular}{|c|c|c|c|}
\hline No & Kategori & Frekuensi & Persentase (\%) \\
\hline 1 & Baik & 19 & 52.8 \\
2 & Cukup & 15 & 41.7 \\
3 & Kurang & 2 & 5.6 \\
\hline \multicolumn{2}{|c|}{ Total } & $\mathbf{3 6}$ & $\mathbf{1 0 0}$ \\
\hline
\end{tabular}

Sumber : Data Primer 
Berdasarkan Tabel $\quad 4.5$ menunjukkan bahwa pengetahuan dari 36 responden tentang gejala Omfalitis, sebanyak 19 responden $(52.8 \%)$ dalam kategori baik, 15 responden $(41.7 \%)$ dalam kategori cukup, dan 2 responden $(5.6 \%)$ dalam kategori kurang.

Tabel 4.6

Distribusi Frekuensi Tingkat Pengetahuan Responden Tentang Pencegahan Omfalitis di Wilayah Kerja Puskesmas Kebunsari Tahun 2015

\begin{tabular}{|c|c|c|c|}
\hline No & Kategori & Frekuensi & Persentase (\%) \\
\hline 1 & Baik & 6 & 16.7 \\
2 & Cukup & 21 & 58.3 \\
3 & Kurang & 9 & 25.0 \\
\hline & Total & $\mathbf{3 6}$ & $\mathbf{1 0 0}$ \\
\hline
\end{tabular}

Sumber : Data Primer

Berdasarkan Tabel 4.6 menunjukkan bahwa pengetahuan dari 36 responden tentang pencegahan Omfalitis, sebanyak 6 responden $(16.7 \%)$ dalam kategori baik,
21 responden $(58.3 \%)$ dalam kategori cukup, dan 9 responden $(25.0 \%)$ dalam kategori kurang.

Tabel 4.7

Distribusi Frekuensi Tingkat Pengetahuan Responden Tentang Omfalitis di wilayah kerja Puskesmas Kebunsari Tahun 2015

\begin{tabular}{|c|c|c|c|}
\hline No & Kategori & Frekuensi & Persentase (\%) \\
\hline 1 & Baik & 11 & $30.6 \%$ \\
2 & Cukup & 24 & $66.7 \%$ \\
3 & Kurang & 1 & $2.8 \%$ \\
\hline \multicolumn{2}{|c|}{ Total } & $\mathbf{3 6}$ & $\mathbf{1 0 0}$ \\
\hline
\end{tabular}

Sumber : Data Primer

Berdasarkan Tabel 4.7 menunjukkan bahwa secara keseluruhan pengetahuan dari 36 responden tentang Omfalitis, sebanyak 11 responden $(30.6 \%)$ dalam PEMBAHASAN

1. Tingkat Pengetahuan Ibu Neonatus Dini 0-7 Hari Tentang Penyebab Omfalitis

Melalui tabel 4.4 dapat diketahui bahwa pengetahuan responden tentang penyebab omfalitis sebanyak 12 responden $(33.3 \%)$ dalam kategori baik, 24 responden $(66.7 \%)$ dalam kategori cukup, dan 0 responden $(0.0 \%)$ dalam kategori kurang.

Responden dalam penelitian ini umumnya memiliki pendidikan sedang yaitu sebanyak 14 orang (38.9\%) tingkat pendidikan SMA, dimana tingkat kategori baik, 24 responden (66.7\%) dalam kategori cukup, dan 1 responden $(2.8 \%)$ dalam kategori kurang.

pendidikan tersebut merupakan tingkat sedang yang dalam pola penerimaannya terhadap suatu informasi terutama mengenai penyebab omfalitis dapat dengan mudah dimengerti. Semakin banyak informasi yang masuk semakin banyak pula pengetahuan yang didapat tentang kesehatan.

Pengetahuan sangat erat kaitannya dengan pendidikan dimana diharapkan seseorang dengan pendidikan semakin. tinggi, maka orang tersebut akan semakin luas pula pengetahuannya. 
Namun berdasarkan hasil penelitian, dalam hal ini tidak semua responden yang berpendidikan rendah, pengetahuannya juga rendah, karena diketahui bahwa ada beberapa responden yang berpendidikan rendah menjawab pertanyaan tentang penyebab omfalitis dalam kategori cukup, hal ini dipengaruhi oleh pengetahuan ibu rumah tangga tersebut yang dapat diperoleh dari pengalaman, kerabatanya, interaksi dalam lingkungan seperti mengikuti penyuluhan kesehatan dan juga memperoleh informasi melalui majalah, koran, televisi, dan radio yang membahas tentang penyebab omfalitis.

Hal ini juga dipengaruhi oleh tingkat usia responden yang dominan berada pada kategori dewasa yaitu 26-35 tahun, yang sudah sewajarnya memiliki tingkat pengetahuan yang cukup luas, dan kecakapannya cukup banyak sehingga mampu memperoleh informasi tentang penyebab terjadinya omfalitis sehingga ia dapat menjauhkan anaknya dari penyebab omfalitis.

Namun dalam hal ini sebagaimana diperoleh dari hasil penelitian bahwa tidak semua responden yang tidak termasuk kategori dewasa yaitu umur $<26$ dan $>35$ tahun menjawab pertanyaan tentang penyebab omfalitis dalam kategori kurang karena berdasarkan penelitian umur responden dalam kategori tersebut menjawab pertanyaan tentang penyebab omfalitis dalam kategori cukup, hal ini dipengaruhi oleh pengetahuan ibu rumah tangga tersebut yang dapat diperoleh dari pengalaman, kerabatanya, interaksi dalam lingkungan seperti mengikuti penyuluhan kesehatan dan juga memperoleh informasi melalui majalah, koran, televisi, dan radio yang membahas tentang penyebab omfalitis.

Berdasarkan jurnal penelitian, Hasil penelitian menunjukkan bahwa sebagian besar responden yang brumur 22-35 berpengetahuan cukup $(43,8 \%),>35$ tahun berpengetahuan baik $(34,4 \%)$, dan masih ditemukan $21,9 \%$ responden yang berumur $<22$ tahun berpengetahuan kurang. Hasil penelitian diperoleh bahwa Pengetahuan Ibu Postpartum Tentang Infeksi Tali Pusat dipengaruh oleh karateristik umur (Suryanti:2009).

2. Tingkat Pengetahuan Ibu Neonatus Dini 0-7 Hari Tentang Gejala Omfalitis

Berdasarkan Tabel 4.5 menunjukkan bahwa pengetahuan dari 36 responden tentang gejala Omfalitis, sebanyak 19 responden $(52.8 \%)$ dalam kategori baik, 15 responden $(41.7 \%)$ dalam kategori cukup, dan 2 responden $(5.6 \%)$ dalam kategori kurang.

Berdasarkan hasil penelitian menunjukkan secara keseluruhan pengetahuan responden tentang gejala omfalitis berada dalam kategori Baik yaitu (52.8\%). Hal ini sesuai dengan karakteristik responden baik dari tingkat usia, pendidikan, dan pekerjaaannya yang sangat mendukung untuk senantiasa memberikan perhatian terhadap kesehatan anaknya.

Dalam penelitian ini umumnya memiliki pendidikan menengah yaitu sebanyak 14 responden (38.9\%) yang berpendidikan SMA, dimana tingkat pendidikan tersebut merupakan tingkat menengah yang dalam pola penerimaannya terhadap suatu informasi terutama mengenai gejala omfalitis dapat dengan mudah dimengerti.

Semakin banyak informasi yang masuk semakin banyak pula pengetahuan yang didapat tentang kesehatan. Pengetahuan sangat erat kaitannya dengan pendidikan dimana diharapkan seseorang dengan pendidikan semakin tinggi, maka orang tersebut akan semakin luas pula pengetahuannya. Sehingga ia mampu mengenali lebih dini jika bayinya mengalami omfalitis.

Namun berdasarkan hasil penelitian, dalam hal ini tidak semua responden yang berpendidikan rendah, pengetahuannya juga rendah, karena diketahui bahwa ada beberapa responden yang berpendidikan rendah menjawab pertanyaan tentang gejala omfalitis dalam kategori cukup, hal ini dipengaruhi oleh pengetahuan ibu 
rumah tangga tersebut yang dapat diperoleh dari pengalaman, kerabatanya, interaksi dalam lingkungan seperti mengikuti penyuluhan kesehatan dan juga memperoleh informasi melalui majalah, koran, televisi, dan radio yang membahas tentang gejala omfalitis.

Jenis pekerjaan responden yang umumnya sebagai URT cukup mendukung hasil penelitian tentang gejala omfalitis yang berkategori baik. Meskipun tidak sesuai dengan teori yang dikemukakan oleh Human (2003), bahwa pekerjaan berhubungan erat dengan faktor interaksi sosial, sedangkan interaksi sosial berhubungan erat dengan proses pertukaran informasi. Dan hal ini tentunya akan mempengaruhi tingkat pengetahuan seseorang.

Namun Dalam hal ini berdasarkan hasil penelitian bahwa ada beberapa responden yang pekerjaannya termasuk Wiraswasta menjawab pertanyaan tentang gejala omfalitis dalam kategori cukup, hal ini dipengaruhi oleh pengetahuan ibu rumah tangga tersebut yang dapat diperoleh dari pengalaman, kerabatanya, interaksi dalam lingkungan seperti mengikuti penyuluhan kesehatan dan juga memperoleh informasi melalui majalah, koran, televisi, dan radio yang membahas tentang gejala omfalitis.

3. Tingkat Pengetahuan Ibu Neonatus Dini 0-7 Hari Tentang Pencegahan Omfalitis.

Berdasarkan Tabel 4.6 menunjukkan bahwa pengetahuan dari 36 responden tentang pencegahan Omfalitis, sebanyak 6 responden (16.7\%) dalam kategori baik, 21 responden $(58.3 \%)$ dalam kategori cukup, dan 9 responden $(25.0 \%)$ dalam kategori kurang.

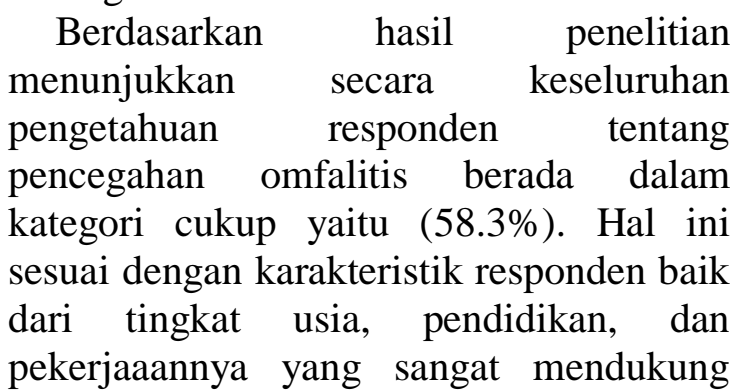

untuk senantiasa memberikan perhatian terhadap kesehatan anaknya.

Responden dalam penelitian ini umumnya memiliki pendidikan menengah yaitu sebanyak 14 responden (38.9\%) yang berpendidikan SMA, dimana tingkat pendidikan tersebut merupakan tingkat menengah yang dalam pola penerimaannya terhadap suatu informasi terutama mengenai cara mencegah terjadinya omfalitis dapat dengan mudah dimengerti.

Namun berdasarkan hasil penelitian, dalam hal ini tidak semua responden yang berpendidikan rendah, pengetahuannya juga rendah, karena diketahui bahwa ada beberapa responden yang berpendidikan rendah menjawab pertanyaan tentang pencegahan omfalitis dalam kategori cukup, hal ini dipengaruhi oleh pengetahuan ibu rumah tangga tersebut yang dapat diperoleh dari pengalaman, kerabatanya, interaksi dalam lingkungan seperti mengikuti penyuluhan kesehatan dan juga memperoleh informasi melalui majalah, koran, televisi, dan radio yang membahas tentang pencegahan omfalitis.

Dipengaruhi oleh tingkat usia responden yang dominan berada pada kategori dewasa yaitu 26-35 tahun, yang sudah sewajarnya memiliki tingkat pengetahuan yang cukup luas, dan kecakapannya cukup banyak sehingga mampu memperoleh informasi tentang cara mencegah terjadinya omfalitis sehingga ia dapat mencegah agar anaknya tidak mengalami omfalitis.

Berdasarkan jurnal penelitian, Hasil penelitian ini menunjukkan bahwa 48 responden, $14(38,9 \%)$ responden berpengetahuan baik, $25(69,4 \%)$ adalah cukup, $9(25,0 \%)$ adalah kurang. Setelah dilakukan penelitian pengetahuan ibu nifas tentang infeksi tali pusat di Kelurahan Bagan PT Kota Jambi menunjukkan bahwa perawatani tali pusat baik pada neonatal berpengaruh pada infeksi tali pusat (Nenny Haryani:2011).

4. Gambaran Pengetahuan Ibu Neonatus Dini 0-7 Hari Tentang Omfalitis 
Bayi baru lahir disebut juga dengan neonatus merupakan individu yang sedang bertumbuh dan baru saja mengalami trauma kelahiran serta harus dapat melakukan penyesuaian diri dari kehidupan intrauterin ke kehidupan ekstrauterin (Vivian Nanny Lia Dewi, 2010).

Berdasarkan Tabel 4.7 menunjukkan bahwa pengetahuan dari 36 responden tentang Omfalitis, sebanyak 11 responden (30.6\%) dalam kategori baik, 24 responden $(66.7 \%)$ dalam kategori cukup, dan 1 responden $(2.8 \%)$ dalam kategori kurang.

Berdasarkan hasil penelitian menunjukkan secara keseluruhan pengetahuan responden tentang omfalitis berada dalam kategori cukup yaitu $(66.7 \%)$. Hal ini sesuai dengan karakteristik responden baik dari tingkat usia, pendidikan, dan pekerjaaannya yang sangat mendukung untuk senantiasa memberikan perhatian terhadap kesehatan anaknya.

Berdasarkan jurnal penelitian, Hasil penelitian diperoleh mayoritas pengetahuan ibu tentang perawatan tali pusat untuk mencegah terjadinya infeksi sebelum penyuluhan adalah cukup sebanyak 31 orang $(83,8 \%)$. Mayoritas pengetahuan ibu tentang perawatan tali pusat untuk mencegah terjadinya infeksi setelah penyuluhan adalah baik sebanyak 31 orang $(83,8 \%)$. Ada perbedaan yang signifikan antara pengetahuan sebelum dan sesudah penyuluhan (Tri Hartini:2009).

\section{KESIMPULAN DAN SARAN}

\section{Kesimpulan}

Berdasarkan hasil penelitian dan pembahasan mengenai Pengetahuan Ibu Neonatus Dini 0-7 Hari Tentang Omfalitis di wilayah kerja Puskesmas Kebunsari, maka dapat ditarik kesimpulan sebagai berikut bahwa hasil penelitian menunjukkan :

1. Tingkat Pengetahuan Ibu Neonatus Dini 0-7 Hari Tentang Penyebab Omfalitis di wilayah kerja Puskesmas Kebunsari adalah sebesar $66.7 \%$ termasuk dalam kategori cukup.
2. Tingkat Pengetahuan Ibu Neonatus Dini 0-7 Hari Tentang Gejala Omfalitis di wilayah kerja Puskesmas Kebunsari adalah sebesar $52.8 \%$ termasuk dalam kategori Baik.

3. Tingkat Pengetahuan Ibu Neonatus Dini 0-7 Hari Tentang Pencegahan Omfalitis di wilayah kerja Puskesmas Kebunsari adalah sebesar 58.3\% termasuk dalam kategori cukup.

4. Tingkat Pengetahuan tentang Gambaran Pengetahuan ibu neonatus dini 0-7 hari tentang omfalitis adalah sebesar $66.7 \%$ termasuk dalam kategori cukup.

\section{DAFTAR PUSTAKA}

Arikunto. Prosedur penelitian. Jakarta : Rineka Cipta. 2006

Adnan Hasan Shalih. Tanggung jawab Ayah Terhadap Laki-laki. 2005

Ahmad Djaeni. Ilmu pendidikan,Jakarta, EGC, 2005

Aslis Wirda Hayati. Buku saku kebidanan. Jakarta, EGC, 2009

Dormatio Rumapa bilongtuyu blogspot.com/2013/05/faktor - faktor yang-

\section{mempengaruhi.html}

Darmaningtyas, Pengetahuan dalam kehidupan masyarakat. Jakarta, salemba medika 2005

Ferry Efendi. Keperawatan Kesehatan Komunitas. Jakarta, Edward Tanuaja, 2009

Handri raharjo, Hukum perusahaan. Yogyakarta : BPFE, 2009

Kusrini. Sistem Pakar Teori dan Aplikasi, CV. Yogyakarta, Andi Offset, 2006

Notoatmodjo. Metodologi Penelitian Kesehatan. Jakarta : PT Rineka Cipta, 2010 
Notoatmodjo. Metodologi Penelitian Kesehatan. Jakarta : PT Rineka Cipta, 2007

Nursalam. Pendidikan dalam Keperawatan. Jakarta, salemba medika, 2008

Rapar, Jan Hendrik, Pengantar filsafat.Yogyakarta, Kanisius, 2010

Sudarminta, J. Episiemologi dasar. Yogyakarta, Kanisius, 2010

Suryanah, Kehidupan dalam bermasyarakat. Jakarta, EGC, 2005

Syafruddin, and Hamidah. Kebidanan Komunitas. Jakarta EGC, 2009

Sodikin, buku saku perawatan tali pusat. Jakarta EGC, 2009

Sinclair, Constance. Buku saku kebidanan. Jakarta. EGC, 2010

Vivian Nanny Lia. Asuhan Neonatus Bayi dan Anak Balita. Jakarta : Salemba

Medika, 2010

Waluya. Sosiologi : Menyelami fenomena sosial dimasyarakat. Bandung, Setia

purna invest, 2007

Widya Ayu Puspita. Buku ajar persalinan dan BBL. Jakarta, 2006 